\title{
Effects of turbulence on the feeding and growth of a marine oligotrich ciliate
}

\author{
John R. Dolan ${ }^{1, *}$, Noura Sall ${ }^{1}$, Aisling Metcalfe ${ }^{2}$, Beat Gasser ${ }^{1}$ \\ ${ }^{1}$ Marine Microbial Ecology Group, LOV, CNRS UMR 7093, BP 28, Station Zoologique, 06230 Villefranche-sur-Mer, France \\ ${ }^{2}$ Department of Applied Mathematics and Theoretical Physics, University of Cambridge, Silver Street, \\ Cambridge CB3 9EW, United Kingdom
}

\begin{abstract}
We investigated the effects of turbulence, using an oscillating grid apparatus, on growth and ingestion in Strombidium sulcatum feeding on picoplankton-sized prey. In batch cultures of ciliates feeding on bacteria, subjected to 4 levels of turbulence ranging from $\varepsilon=0.005$ to $2.0 \mathrm{~cm}^{2} \mathrm{~s}^{-3}$ or still water, we found a negative effect of turbulence on growth rate. Examination of turbulenceincubated cells showed no evidence of arrested cell division, known in some dinoflagellate species. Ingestion rates, measured using fluorescent microspheres, were lower under turbulent conditions. A prey selection experiment with microspheres of different surface qualities showed similar, previously established, patterns of selective ingestion but at lower rates under turbulent conditions. In ciliate cultures subjected to turbulence intermittently for $5 \mathrm{~d}$ ( $24 \mathrm{~h}$ on, $24 \mathrm{~h}$ off), population declines were followed by increases. We discuss a model of the effects of turbulence on predator-prey contact rates and suggest that our data reflect behavioral changes under turbulent conditions, which results in lower ingestion rates leading to lower growth rates.
\end{abstract}

KEY WORDS: Microzooplankton $\cdot$ Grazing $\cdot$ Behavior $\cdot$ Plankton

Resale or republication not permitted without written consent of the publisher

\section{INTRODUCTION}

Turbulence is known to influence the community composition of phytoplankton and thus the structure of pelagic food webs (reviewed in Kiørboe 1993). For example, turbulent environments are associated with a dominance of diatom taxa (e.g. Margalef 1978) and periodic calm seas conditions - 'Lasker Events' - with blooms of dinoflagellates (Pauly 1989). Diatoms, perhaps because of their relatively low sinking rates (e.g. Smayda \& Bienfang 1983) appear well-adapted to turbulent waters. In contrast, certain dinoflagellate species appear to be negatively influenced by turbulence. Turbulence has been shown to be associated with lower growth rates, based on data from both laboratory studies (White 1976, Thomas \& Gibson 1990, 1992, Berdalet 1992, Berdalet \& Estrada 1992, Thomas et al. 1995) as well as field work (Pollingher \& Zemel 1981).

Turbulence is also known to influence particlefeeding zooplankton and nekton. Results from early mesocosm studies suggested that turbulence was associated with negative effects on the development of zooplankton biomass, but how turbulence could affect particle-feeding organisms was unclear (e.g. Oviatt 1981). Focusing on the feeding of larval fish, a possible mechanism was identified by Rothschild \& Osborne (1988), who pointed out that fluid motion should be considered, and could be modeled, in predator-prey interactions. They described turbulence as a force with a net effect of increasing the contact rate of predators and their prey. The precise effects were found to be non-linear and influenced by the feeding strategy employed by the larval fish (Kiørboe \& MacKenzie 1995, MacKenzie \& Kiørboe 1995). Further complications were recently brought to light in the form of the negative effects of intermittent turbulence on prey pursuit in larval fish (MacKenzie \& Kiørboe 2000).

Among the zooplankton, the theoretical influence of turbulence, that of increasing ingestion rates by increasing predator-prey contact rates and thereby 
ingestion, appeared to be confirmed in early studies of copepod feeding (Marrasé et al. 1990, Saiz et al. 1992). However, subsequent investigations revealed a further complexity, that is, that a 'benefit' depends on the type of feeding behaviour employed by the copepod (Kiørboe \& Saiz 1995) and that copepod behavior changes with the turbulence environment (Costello et al. 1990, Saiz 1994, Saiz \& Kiørboe 1995, Caparroy et al. 1998).

For micro and nanozooplankton, microscale shear as a result of turbulence was hypothesized to quite possibly result in increased contact rates between nanoflagellates or ciliates and their prey (Shimeta \& Jumars 1991). Experimental work thus far has shown inconsistent results. Working with natural populations of nanoand microzooplankton, bacterivory rates appeared to increase with turbulence, compared to 'still water', while estimates of ingestion rates of a typical flagellate bactivore showed no effect (Peters \& Gross 1994, Peters et al. 1996). In a series of laboratory experiments with a variety of protists, Shimeta et al. (1995) found significant enhancement of feeding rates with turbulence in particle-associated forms of flagellates, but no effect on motile flagellates. Three ciliate species were examined: 2 tintinnids, Helicostomella and Favella, and a heterotrich (likely a Euplotes species); turbulence reportedly had no effect on the heterotrich or Favella but reduced ingestion in Helicostomella by about $50 \%$. To our knowledge, there exists no data on the effects of turbulence on oligotrich ciliates, forms which generally dominate the microzooplankton, and existing data on other microzooplankters or nanozooplankters do not allow reasonable prediction of the effects of turbulence on oligotrich ciliates. Interestingly, oligotrich ciliates have been used as prey items in turbulence studies (e.g. Saiz \& Kiørboe 1995, Capparoy et al. 1998).

Here we present data from a series of laboratory experiments with the bactivorous oligotrich ciliate Strombidium sulcatum. We focused on S. sulcatum, rather than a strictly algivorous oligotrich species, because there is a great deal of data on the physiological ecology of $S$. sulcatum, especially on feeding (Bernard \& Rassoulzadegan 1990, Dolan \& Simek 1997, Christaki et al. 1998, 1999) growth (Rivier et al. 1985, Allali et al. 1994) and behavior (Fenchel \& Jonsson 1988). We examined growth rates in batch cultures subjected to turbulence regimes, ranging from a level similar to that found in waves, to still water. We estimated feeding rates and selective feeding in turbulent and still water using fluorescent microspheres. We considered the reversibility of turbulence effects through an 'on-off' experiment. We interpret our findings of reduced ingestion and growth with turbulence in $S$. sulcatum as likely the result of turbulenceinduced alterations in swimming speed or pattern.

\section{MATERIALS AND METHODS}

Turbulence generation. An oscillating grid device, similar to that described in Peters et al. (2002), was used to generate different levels of turbulence. Grids were made of stainless steel coated with a plastic polyamide. Movement was provided by 4 independently controlled motors, each attached to a frame holding 2 grid shafts. Thus, replicate containers for up to 4 different levels of grid movement could be used. Grids moved up and down inside 21 plexiglass lidded containers, traversing the entire water column. In the first experiment, we employed a stroke radius of $7.5 \mathrm{~cm}$ and frequencies of $1,2.5,10$ and $20 \mathrm{rpm}_{\text {; the }}$ respective levels of turbulence levels, calculated following Peters \& Gross (1994) as epsilon ( $(\varepsilon)$, which is the turbulent kinetic energy dissipation rate, were then $0.005,0.032,0.515,2.058 \mathrm{~cm}^{2} \mathrm{~s}^{-3}$. In the second, third and fourth experiments we used $1 \mathrm{l}$ volumes, a stroke radius of $3.25 \mathrm{~cm}$ and a frequency of $5 \mathrm{rpm}$, which generates turbulence intensity as epsilon estimated to be about $0.041 \mathrm{~cm}^{2} \mathrm{~s}^{-3}$.

Expt 1-Growth. In the first experiment we monitored ciliate growth over $7 \mathrm{~d}$ among populations in still water and subjected to 4 different levels of turbulence. The oligotrich ciliate Strombidium sulcatum was grown using wheat grain cultures, as previously described (Christaki et al. 1998), at the experimental temperature of $17^{\circ} \mathrm{C}$. An aliquot of a late log-phase ciliate culture was added to 201 of $0.22 \mu \mathrm{m}$ filtered seawater, supplemented with Difco Marine Broth (0.05 $\left.\mathrm{g} \mathrm{l}^{-1}\right)$ to permit the growth of bacterial prey. In the 201 solution, the initial concentration of ciliates was 10 cells ml ${ }^{-1}$ and that of bacteria $3 \times 10^{6}$ cells $\mathrm{ml}^{-1}$. The solution was dispensed into 10 plexiglass containers of $2 \mathrm{l}$ volume. Pairs of containers were subjected to 1 of 4 levels of turbulence, generated using an oscillating grid apparatus described in the first section; 2 were left untouched as still water containers.

The turbulence levels theoretically generated were $2,0.5,0.03$, and 0.005 values of $\varepsilon\left(\mathrm{cm}^{2} \mathrm{~s}^{-3}\right)$. These rates, based on values reported from a variety of environments, roughly represent turbulence levels in breaking waves, a tidal front, coastal surface waters, and open ocean surface waters according to Petersen et al. (1998).

Samples for determination of concentrations of ciliates and bacteria were taken from each container at time zero, after $6 \mathrm{~h}$, and then daily for $7 \mathrm{~d}$. For sampling, water in the containers was thoroughly mixed and $20 \mathrm{ml}$ aliquots removed, one subsequently preserved with acid Lugol's ( $2 \%$ final conc.) for ciliate counts and the other fixed with formaldehyde for bacterial counts. Samples for ciliate counts were sedi- 
mented in counting chambers and examined with an inverted microscope. Bacteria were enumerated from DAPI-stained aliquots using epifluorescence microscopy. Rates of change in ciliate concentrations were calculated using the exponential model: $N_{t}=N_{0} \mathrm{e}^{(r t)}$. Linear regression of $\ln$ ciliate concentrations vs time was used to generate estimates of growth rates with associated probabilities and standard errors.

Samples from Day 3 of each treatment were further examined to determine ciliate cell volumes and control for obvious differences in macronuclear morphology. Samples from Day 3 were chosen for ease of sample processing because cell concentrations were sufficiently high in all containers. In Lugol's preserved samples from each treatment, linear dimensions of 50 cells were measured with an ocular micrometer. Cell volumes were calculated following the formula presented by Ohman \& Snyder (1991) for a conical oligotrich. Oligotrich nuclei were examined by adding DAPI to formaldehyde-preserved samples and examining sedimented cells using an inverted epifluorescence microscope.

Expt 2-Ingestion. In the second experiment, we estimated ingestion rates of ciliates under intermediate turbulent conditions compared to still water, using fluorescent microspheres as prey analogs (Børsheim 1984). As in the first experiment, a late log-phase culture of ciliates was mixed into a large volume (8 l) of $0.22 \mu \mathrm{m}$ filtered seawater amended, to assure minimal bacterial growth, with marine broth $\left(0.05 \mathrm{~g} \mathrm{l}^{-1}\right)$. Samples were taken for bacterial counts. Subsequently, 11 aliquots of the ciliate solution were dispensed into 8 plexiglass containers, 4 left untouched and 4 subjected to turbulence estimated as epsilon $=0.04 \mathrm{~cm}^{2}$ $\mathrm{s}^{-3}$. For each treatment, still and turbulent conditions, a pair of containers was destined to provide estimates of ingestion rates at time zero, and the other pair for estimates after $3 \mathrm{~d}$ of incubation.

Beginning with the still water containers, 2 containers were inoculated with a sonicated solution of $1.0 \mu \mathrm{m}$ diameter 'plain' yellow-green fluorescent microspheres to yield a final concentration of 50000 microspheres $\mathrm{ml}^{-1}$. Samples were taken from each after $30 \mathrm{~min}$ and preserved with alkaline Lugol's solution (1\% final conc.). After $1 \mathrm{~h}$ of turbulence incubation, fluorescent microspheres were injected and mixed thoroughly into 2 of the 4 turbulence containers. After $30 \mathrm{~min}$, samples were removed and preserved as for the still water containers. For the 4 remaining containers, incubation continued for $3 \mathrm{~d}$. Then, the entire process of inoculation with microspheres and sampling after 30 min was repeated. Following the microsphere ingestion experiments, samples were taken for ciliate and bacterial enumerations and processed as described above.
Ingestion rates were estimated by counting microspheres inside individual ciliates in samples from each of the 8 containers. To estimate ingestion by ciliates after $3 \mathrm{~d}$ of turbulence incubation, entire volumes of the containers were preserved and cells concentrated by settling in graduated cylinders. Sample aliquots, either whole water or pre-concentrated material, were sedimented in settling chambers, and just prior to examination samples were bleached with a sodium thiosulfate solution (Sherr \& Sherr 1993) for fluorescence microscopy. Using material from each container, 50 to 100 well-preserved cells were located using transmitted light and then microspheres inside the cells counted using epifluorescence at a magnification of $400 \times$. For each sample, an average ingestion rate, microspheres per cell, was calculated and transformed into an hourly clearance rate, which is the volume of water swept clear of microspheres per hour.

Expt 3-Selective ingestion. We compared, under still and turbulent conditions, ingestion of similarsized (1.0 $\mu \mathrm{m}$ diameter) plain and carboxylate microspheres, known from previous work to be ingested at different rates in still water experiments (Christaki et al. 1998). Similar to Exps 1 and 2, a late log-phase culture of ciliates was decanted into a $0.22 \mu \mathrm{m}$ filtered seawater and dispensed into $4 \times 1 \mathrm{l}$ containers. Two containers were subjected to turbulence as in Expt 2. Then, all 4 containers received fluorescent microspheres to yield final concentrations of 60000 microspheres $\mathrm{ml}^{-1}$ of 'yellow-green' plain microspheres and 60000 microspheres $\mathrm{ml}^{-1}$ of 'red' carboxylate microspheres. Samples were taken and preserved as in Expt 2, on average $15 \mathrm{~min}$ after microsphere introduction. The incubation period was reduced, relative to Expt 2, to account for the higher prey analog concentrations employed, which were required to give a measurable ingestion of the 'lesspreferred' carboxylate microspheres. Samples were processed as in Expt 2, with the difference of enumerating distinct types of microspheres (which appear as yellow or red using fluorescence microscopy) inside the ciliates.

Expt 4-Intermittent turbulence. Similar to the first experiment, a culture of ciliates (stationary phase) was mixed into a large volume (10 l) of $0.22 \mu \mathrm{m}$ filtered seawater amended, to assure minimal bacterial growth, with marine broth $\left(0.05 \mathrm{~g} \mathrm{l}^{-1}\right)$. One liter aliquots of the ciliate solution were dispensed into 9 plexiglass containers. Three containers were left untouched (still water), 3 subjected to turbulence for $24 \mathrm{~h}$ followed by $24 \mathrm{~h}$ of no turbulence (turbulence 'on-off'), and 3 containers subjected to constant turbulence. Turbulence was estimated as $0.04 \mathrm{~cm}^{2} \mathrm{~s}^{-3}$ Containers were sampled daily for $5 \mathrm{~d}$. 

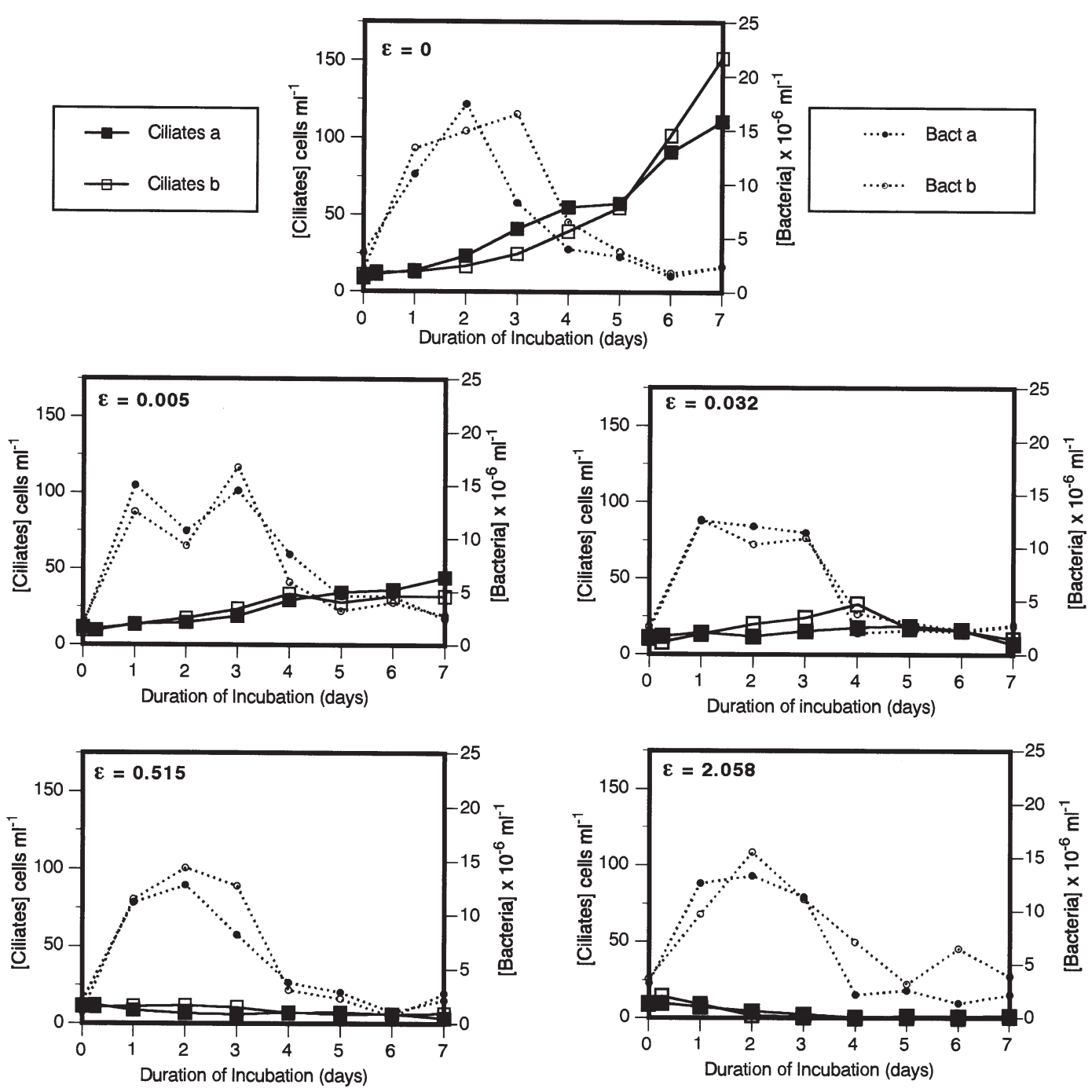

Fig. 1. Temporal changes in concentrations of Strombidium sulcatum ciliates and bacteria in the turbulence ( $\varepsilon$ values in the upper right, see text for details) and growth experiment. Open and closed symbols represent different replicates. Growth rate estimates appear in Table 1

\section{RESULTS}

\section{Growth experiment}

Ciliate counts from samples removed from the cultures after $6 \mathrm{~h}$ of incubation showed no immediate effect of turbulence on Strombidium sulcatum (Fig. 1). After $1 \mathrm{~d}$ of incubation, bacterial concentrations in the containers increased from $3 \times 10^{6}$ to $10-13 \times 10^{6}$ bacteria $\mathrm{ml}^{-1}$, and began to decline from Day 2 or 3, presumably due to the exhaustion of the small amount of substrate added $\left(0.05 \mathrm{~g} \mathrm{l}^{-1}\right)$, and perhaps attachment to container walls. Over the $7 \mathrm{~d}$, ciliate concentrations increased from 11 to about 100 cells ml ${ }^{-1}$ in the still water containers, compared to a peak of 40 cells ml$^{-1}$ in the low turbulence treatment. Based on samples from containers subjected to intermediate to high turbulence intensities, either no growth or declines in ciliate concentrations were recorded.

Growth rates, or exponential changes in cell concentrations, calculated over the first $4 \mathrm{~d}$ period, when bacterial concentrations were high and thus ciliates were not food-limited, showed a distinct pattern with turbulence intensity. In the incubations, ciliate growth rates declined with increases in turbulence level (Table 1, Fig. 2). While the effect of low levels of turbulence was unclear, intermediate levels impacted growth and cell death occurred with turbulence intensities above $0.1 \mathrm{~cm}^{2} \mathrm{~s}^{-3}$. Overall, there was a significant negative relationship between turbulence level and growth rate. 


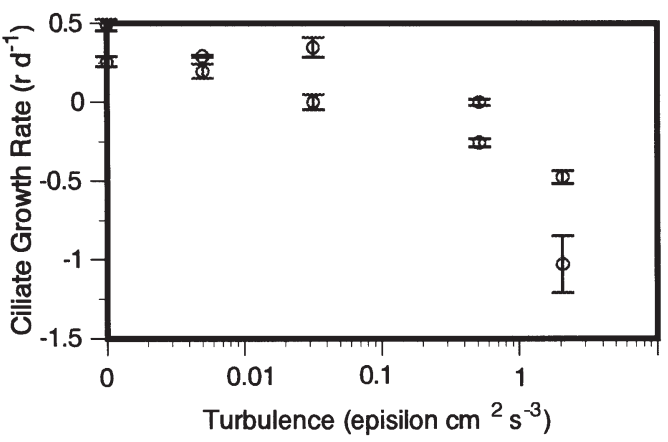

Fig. 2. Strombidium sulcatum. Growth rates, or exponential rates of change, of ciliate populations in Expt 1, calculated over the first $4 \mathrm{~d}$ of incubation. Growth rate was negatively related to turbulence level using simple linear regression: $y=$ $0.241-(0.497 x), r^{2}=0.818, p=0.0003$

Comparing ciliate nuclear morphology in DAPIstained samples from Day 3 of the incubation, we found no obvious pattern of arrested nuclear fission stages (data not shown). Examining cell volumes from each treatment, using Lugol's-fixed samples from Day 3 , we found considerable variability within populations, which translated into large variance around mean values, resulting in finding no significant differences between mean cell volumes (i.e. $p=0.07$ ). However, plotting distributions of cell volumes showed some interesting differences between populations subjected to different levels of turbulence (Fig. 3). Even in the still water samples in which ciliates were dividing rapidly, large cells likely in the process of division were very rare. However we found that ciliate populations from intermediate and high turbulence regimes contained a large proportion of small cells, presumably representing either starved old cells or recently divided cells.

Table 1. Strombidium sulcatum. Results of regression analysis used to estimate growth rates (ln cell concentrations vs. time over the first $4 \mathrm{~d}$; see text for details) under different conditions; Expt 1

\begin{tabular}{|lccr|}
\hline $\begin{array}{l}\text { Treatment } \\
\text { (replicate) }\end{array}$ & $\begin{array}{c}\text { Growth rate } \\
( \pm \mathrm{SE})\end{array}$ & $\mathrm{r}^{2}$ & $\mathrm{p}$-value \\
\hline Still, $\varepsilon=0$ (a) & $0.490 \pm 0.035$ & 0.985 & 0.0008 \\
Still, $\varepsilon=0$ (b) & $0.256 \pm 0.033$ & 0.953 & $<0.0044$ \\
$1 \mathrm{rpm}, \varepsilon=0.005(\mathrm{a})$ & $0.196 \pm 0.046$ & 0.858 & 0.0238 \\
$1 \mathrm{rpm}, \varepsilon=0.005(\mathrm{~b})$ & $0.292 \pm 0.006$ & 0.999 & 0.0004 \\
$2.5 \mathrm{rpm}, \varepsilon=0.032(\mathrm{a})$ & $0.080 \pm 0.049$ & 0.473 & 0.1999 \\
$2.5 \mathrm{rpm}, \varepsilon=0.032(\mathrm{~b})$ & $0.347 \pm 0.062$ & 0.912 & 0.0113 \\
$10 \mathrm{rpm}, \varepsilon=0.515(\mathrm{a})$ & $-0.256 \pm 0.025$ & 0.971 & 0.0021 \\
$10 \mathrm{rpm}, \varepsilon=0.515(\mathrm{~b})$ & $-0.006 \pm 0.021$ & 0.032 & 0.7740 \\
$20 \mathrm{rpm}, \varepsilon=2.058(\mathrm{a})$ & $-0.775 \pm 0.04$ & 0.979 & 0.0013 \\
$20 \mathrm{rpm}, \varepsilon=2.058(\mathrm{~b})$ & $-1.028 \pm 0.18$ & 0.915 & 0.0107 \\
\hline
\end{tabular}

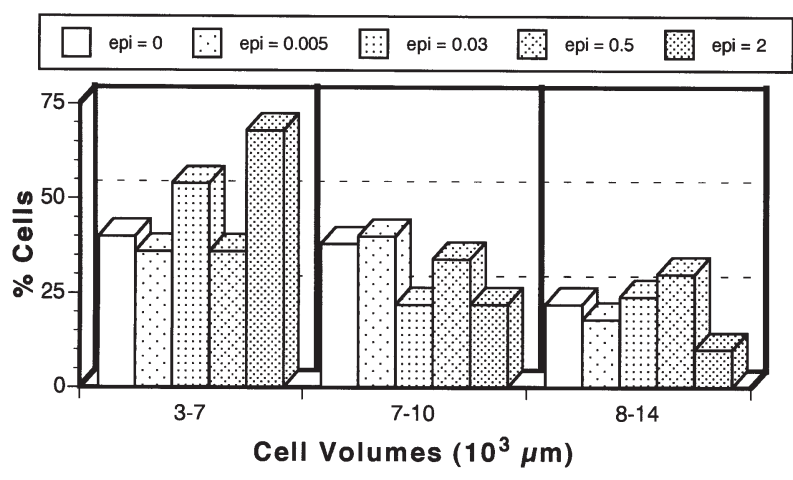

Fig. 3. Strombidium sulcatum. Distribution of cell volumes among ciliate populations after $3 \mathrm{~d}$ of incubation under different turbulence regimes $\left(\mathrm{epi}=\varepsilon, \mathrm{cm}^{2} \mathrm{~s}^{-3}\right)$. Note that the ciliate populations from intermediate and high turbulence treatments contained a high portion of small cells

\section{Ingestion experiment}

The incubations gave results similar to those of the first experiment in terms of changes in organismal concentrations. Ciliate concentrations increased in the still water containers from an initial value of 14 to about 40 cells ml ${ }^{-1}$ while those in the turbulence containers decreased to about 2 cells $\mathrm{ml}^{-1}$, despite similar bacterial concentrations $\left(2-4 \times 10^{6}\right.$ bacteria $\left.\mathrm{ml}^{-1}\right)$ in the 2 sets of containers (Table 2).

At the beginning of the incubations, microsphere ingestion by ciliates in still water was about 4 times that of cells held in water exposed to turbulence (estimated as $\varepsilon=0.05 \mathrm{~cm}^{2} \mathrm{~s}^{-3}$ ). Calculated clearance rates for still water and turbulent water ciliates were, respectively, about 200 compared to $50 \mathrm{nl} \mathrm{cell}^{-1} \mathrm{~h}^{-1}$ (Fig. 4). Ingestion measured after $3 \mathrm{~d}$ gave results similar to those at the beginning of the incubation, except that still water ciliates fed slightly less. Apparent clearance rates of still water ciliates were approximately $150 \mathrm{nl}$ ciliate $^{-1} \mathrm{~h}^{-1}$ and those of turbulence-incubated ciliates remained unchanged at $50 \mathrm{nl}$ ciliate $\mathrm{e}^{-1} \mathrm{~h}^{-1}$.

Examination of the distribution of microspheres in ciliates from the still water and turbulent incubations

Table 2. Strombidium sulcatum. Final organismal abundance from Expt 2 in which ciliate ingestion was estimated before and after $3 \mathrm{~d}$ of incubation under still or turbulent $\left(\varepsilon=0.04 \mathrm{~cm}^{2}\right.$ $\mathrm{s}^{-3}$ ) conditions. Initial concentrations were 14 ciliates $\mathrm{ml}^{-1}$ and $1 \times 10^{6}$ bacteria $\mathrm{ml}^{-1}$

\begin{tabular}{|lcccc|}
\hline & \multicolumn{3}{c}{ Still water } & \multicolumn{2}{c|}{ Turbulence } \\
Replicate: & a & b & a & b \\
\hline Ciliates $\mathrm{ml}^{-1}$ & 36 & 42 & 14 & 14 \\
Bacteria $\times 10^{6} \mathrm{ml}^{-1}$ & 3.1 & 2.5 & 4.0 & 2.1 \\
\hline
\end{tabular}




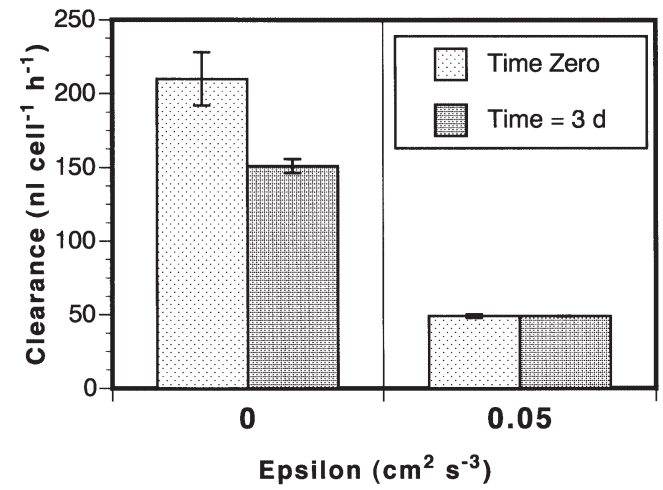

Fig. 4. Strombidium sulcatum. Comparison of average clearance rates, based on ingestion of microspheres, of ciliates in still water and those subjected to turbulence at the beginning and end of a $3 \mathrm{~d}$ incubation. Error bars show the range of estimates. Changes in cell concentrations over the incubation period are given in Table 2

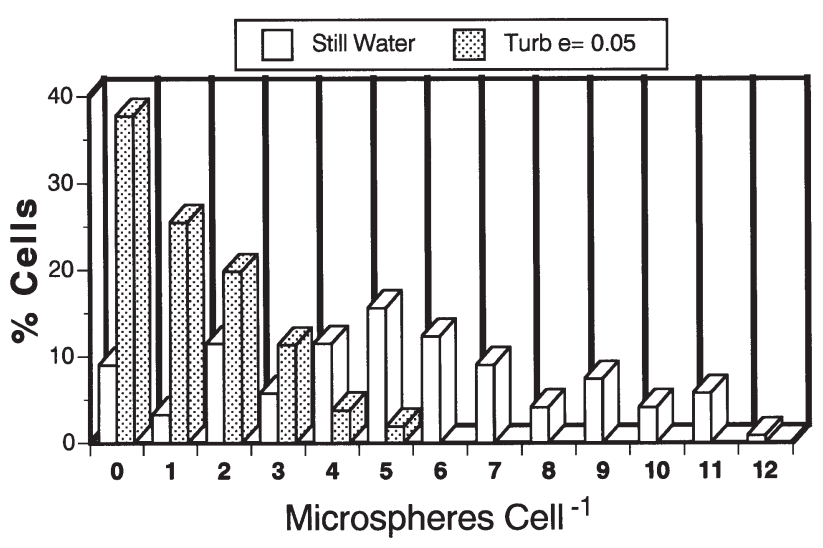

Fig. 5. Strombidium sulcatum. Distribution of microspheres in ciliates exposed to microspheres in still water and turbulent incubations. Data was pooled from both sets of replicates at the beginning of the $3 \mathrm{~d}$ incubation period (see Fig. 4). Note that the distribution from the turbulence incubation, relative to the still water incubation, shows a large portion of cells without ingested microspheres

showed that the still water incubated cells displayed a normal distribution of microsphere ingestion. The lower average ingestion rate of turbulence-incubated ciliates reflected the fact that a large portion of turbulence-incubated cells had not ingested microspheres (Fig. 5).

\section{Selective feeding}

Oligotrichs feeding in still water fed on plain microspheres at about twice the rate they ingested carboxylate microspheres. A similar relationship of carboxylate microspheres ingested at half the rate of plain micro-

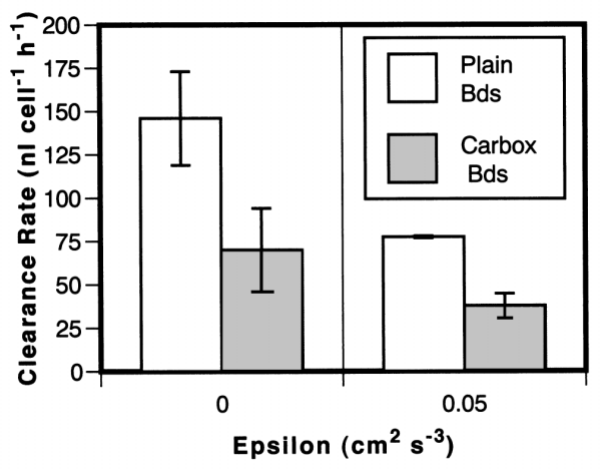

Fig. 6. Strombidium sulcatum. Comparison of average clearance rates of 2 different types of $1 \mu \mathrm{m}$ diameter fluorescent microspheres, plain and carboxylate, by populations of ciliates in still water and those subjected to turbulence. Epsilon in the turbulence treatment was estimated to be $0.05 \mathrm{~cm}^{2} \mathrm{~s}^{-3}$. Error bars show the range of estimates

spheres was apparent for cells feeding under turbulent conditions. As was found in Expt 2, ingestion and calculated clearance rates in cells subjected to turbulence were about half those estimated for still-water incubated cells (Fig. 6).

\section{Intermittent turbulence}

Ciliates increased then decreased in concentrations in containers subjected to 'on-off' turbulence, compared to positive growth in still water, or declines in cells with constant turbulence (Fig. 7). Growth rates (Table 3) estimated over the incubation period were positive in the still water containers, not significantly different from zero in the 'on-off' containers and negative in the turbulence containers (except for 1 replicate).

\section{DISCUSSION}

Data from the first growth experiment suggests a negative effect of turbulence on the growth of Strombidium sulcatum (Figs. 1 \& 2, Table 1). We examined cell morphologies seeking evidence of arrested cell division, or distinct changes in morphology, associated with turbulence as is found among some dinoflagellates (Berdalet 1992, Thomas et al. 1995, Zirbel et al. 2000). We found only that populations from the highest turbulence treatments displayed relatively high proportions of small cells (Fig. 3). As reductions in cell volumes accompany starvation in $S$. sulcatum (Fenchel \& Jonsson 1988), interference with feeding appeared to be the simplest explanation for a negative effect of turbulence. 

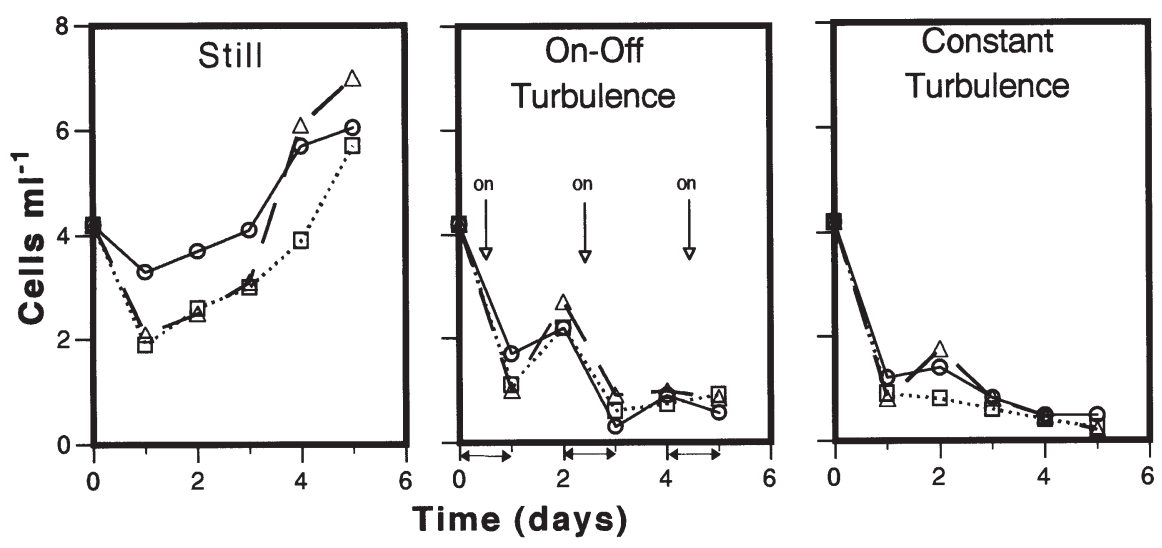

Fig. 7. Strombidium sulcatum. Temporal changes in concentrations of ciliates in containers subjected to 'on-off' turbulence for $24 \mathrm{~h}$ periods (see text for details), compared to still water or constant turbulence. Distinct symbols represent distinct replicates. Growth rate estimates appear in Table 3

Our feeding experiments, based on the ingestion of fluorescent microspheres, provided evidence of a reduction in feeding rate under turbulent conditions (Fig. 4). The rates we estimated in incubations without turbulence, ca. 150 to $200 \mathrm{nl} \mathrm{cell}{ }^{-1} \mathrm{~h}^{-1}$, are close to those previously reported by Christaki et al. (1998) of about $175 \mathrm{nl}$ cell $^{-1} \mathrm{~h}^{-1}$ for Strombidium sulcatum clearance of $1 \mu \mathrm{m}$ diameter plain microspheres. In contrast, populations of ciliates which were incubated in turbulence, for either $<1 \mathrm{~h}$ or $3 \mathrm{~d}$, ingested microspheres at rates equivalent to $1 / 4$ to $1 / 3$ of the still water population. We examined the distribution of ingested microspheres within the populations of ciliates and found that in turbulence incubated populations, a large portion of the population was either not feeding, or feeding at less than detectable levels. Thus microsphere ingestion rates supported the idea that turbulence interfered with feeding, leading to lower or no growth of the populations incubated with turbulence (Fig. 1).

Table 3. Strombidium sulcatum. Results of regression analysis used to estimate growth rates (ln cell concentrations vs. time over the 5 d period) under different conditions; Expt 2

\begin{tabular}{|lccc|}
\hline $\begin{array}{l}\text { Treatment } \\
\text { (replicate) }\end{array}$ & $\begin{array}{c}\text { Growth rate } \\
( \pm \mathrm{SE})\end{array}$ & $\mathrm{r}^{2}$ & $\mathrm{p}$-value \\
\hline Still (a) & $0.260 \pm 0.022$ & 0.980 & 0.0012 \\
Still (b) & $0.164 \pm 0.023$ & 0.940 & 0.0054 \\
Still (b) & $0.330 \pm 0.049$ & 0.937 & 0.0069 \\
On-off (a) & $-0.150 \pm 0.161$ & 0.226 & 0.4183 \\
On-off (b) & $-0.311 \pm 0.236$ & 0.368 & 0.2779 \\
On-off (c) & $-0.136 \pm 0.158$ & 0.446 & 0.4514 \\
Turbulence (a) & $-0.334 \pm 0.044$ & 0.950 & 0.0048 \\
Turbulence (b) & $-0.290 \pm 0.072$ & 0.843 & 0.0278 \\
Turbulence (c) & $-0.411 \pm 0.172$ & 0.656 & 0.0965 \\
\hline
\end{tabular}

We further examined the influence of turbulence on feeding by considering selective ingestion. In Strombidium sulcatum, prey items differing in size and/or surface characteristics are ingested at different rates. For example, among the autotrophic picoplankters Synechococcus and Prochlorococcus, Synechococcus is ingested at a rate about 10 times that of Prochlorococcus (Christaki et al. 1999) and plain microspheres of $1 \mu \mathrm{m}$ diameter are ingested about 2.5 times the rate of carboxylate microspheres (Christaki et al. 1998). We believed that if turbulence interfered in some manner with particle handling then this could be reflected by a change in selectivity among particles. Our data suggests that particle discrimination is unchanged, as a very similar pattern, that of plain microspheres ingested at 2.5 times the rate of carboxylate microspheres (Fig. 6), was shown by ciliates in both still and turbulent water. Thus, we found no evidence of turbulence affecting the qualitative manner in which particles are handled by $S$. sulcatum.

If prey selection is similar in still and turbulent treatments, differences in prey encounter rates could explain different ingestion rates. Models of predatorprey encounter generally include rates of predator motion, prey motion and a contact radius or surface over which prey are encountered (e.g. Gerritsen \& Strickler 1977). Newer mathematical models, such as that of Lewis \& Pedley (2000), include separate components of motion due to predator and prey swimming, turbulence and contact radius of the predator (Fig. 8). Such models, or system of equations, provide a means of dissecting predator-prey encounter rates so that it is possible to calculate the value of an individual component, given values for the other components.

We experimentally generated values of ingestion and turbulence, so the system of equations can provide estimates of 'contact radius' in still water by substitut- 
Table 4. The system of equations from Lewis \& Pedley (2000) relating contact rate (considered here as clearance rate) to: (1) swimming speeds of predator and prey, (2) the contact radius of the predator and (3) a turbulence component. Through numerical simulation, the system of equations can provide 'swimming speed' given clearance rate and contact radius. Conversely, assuming a contact radius and given a clearance rate, a swimming speed can be calculated

$$
\begin{aligned}
& \mathrm{CR}=\pi \rho_{H} R^{2}\left[\frac{8}{\pi} \omega_{T}^{2}+v_{H}^{2}+v_{P}^{2}\right]^{\frac{1}{2}} \\
& \omega_{T}^{2}=\varepsilon^{\frac{2}{3}} R^{\frac{2}{3}}\left[S_{C}-3\left(\frac{\eta}{R}\right)^{\frac{2}{3}}+2 \int_{\frac{R}{\eta}}^{\infty} \frac{\sin x}{x^{\frac{8}{3}}} \mathrm{~d} x\right]
\end{aligned}
$$

$\mathrm{CR}$ is the contact rate as number of prey encountered per unit time

$\rho_{H}$ is the prey density as number of cells per unit volume

$R$ is the contact radius, the distance over which a preda-

tor can perceive its prey

$\omega_{T}^{2}$ is the turbulent velocity scale

$v_{H}$ is the prey swimming speed

$v_{P}$ is the predator swimming speed

$\varepsilon$ is the turbulent kinetic energy dissipation rate

$S_{C}=2.411$ is the stucture function constant for the turbulent energy spectrum

$\eta=\left(\frac{v^{3}}{\langle\varepsilon\rangle}\right)^{\frac{1}{4}}$ is the Kolmogorov microscale

$v=10^{-6} \mathrm{~m}^{2} \mathrm{~s}^{-1}$ is the kinematic viscosity of water

ing our measured values of ingestion for 'contact rate' and a swimming speed of $600 \mu \mathrm{m} \mathrm{s}^{-1}$ (Fenchel \& Jonsson 1988, verified with rough estimates from $15 \mathrm{~s}$ films of swimming in plankton counting chambers).

Once a contact radius is estimated, as we have values of ingestion for a given level of turbulence, we can estimate swimming speed for that level of turbulence. Conversely, we can assume a swimming speed and estimate 'contact radius' for the level of turbulence employed. Thus, the model can provide estimates of changes in a single parameter (either swimming speed or contact radius) sufficient to explain the changes we observed in ingestion associated with turbulence. In the discussion which follows, it should be understood that equating ingestion to contact implies a $100 \%$ particle capture efficiency, which is unlikely to be true. Hence, our calculations serve only to provide estimates of the possible relative, not absolute, values of changes in parameters.

Employing values from the still water incubations, the 'contact radius' in still water is $5.4 \mu \mathrm{m}$, given that turbulent velocity is zero, a prey (microsphere) concentration of $50000 \mathrm{ml}^{-1}$, a prey swimming speed of zero, predator speed of $600 \mu \mathrm{m} \mathrm{s}^{-1}$ and a contact rate equivalent to ingestion of 10 microspheres $\mathrm{h}^{-1}$ (= clearance of $200 \mathrm{nl} \mathrm{h}^{-1}$ ). The calculated contact radius of $5.4 \mu \mathrm{m}$ agrees well with the radius of the oral area of Strombidium sulcatum (Fig. 1 in Fenchel \& Jonsson 1988, Fig. 3 in Montagnes et al. 1990). We can now, with our estimate of contact radius and contact rate (here as ingestion), calculate swimming speed of the ciliate for the experimental turbulence level.

Given a turbulence level of $0.05 \mathrm{~cm}^{2} \mathrm{~s}^{-3}$ and a contact radius of $5.4 \mu \mathrm{m}$, the turbulent velocity can be calculated numerically using a computer algebra package such as Maple. This value can then be substituted into Eq. (a) of Table 4, with prey density and swimming speed as before. Employing the experimentally estimated contact rate of 3.75 microspheres $\mathrm{h}^{-1}$ (= clearance rate of $75 \mathrm{nl} \mathrm{h}^{-1}$ ), yields a ciliate swimming speed of $230 \mu \mathrm{m} \mathrm{s}^{-1}$. Thus, our analysis suggests that turbulence could be associated with a reduction of ca. $2 / 3$ in the volume of water examined, through either a slower absolute speed or a change in swimming pattern, for example a more circular swimming pattern. Conversely, one may consider the possibility that swimming speed remains unchanged but a change in contact radius is associated with turbulence.

Calculating contact radius for turbulent flow is more complicated, because the turbulent velocity scale depends on contact radius. In Table 4, squaring Eq. (a) and substituting Eq. (b) for the turbulent velocity scale gives a nonlinear equation for contact radius which must be solved numerically. For a contact rate of 3.75 microspheres $\mathrm{h}^{-1}$, a prey (microsphere) density of $50000 \mathrm{ml}^{-1}$, a ciliate swimming speed of $600 \mu \mathrm{m} \mathrm{s}^{-1}$ and a prey swimming speed of 0 , the contact radius is $3.3 \mu \mathrm{m}$. In physical terms, it is difficult to imagine how contact radius, which is a measure of a cross-sectional area of 'prey contact' could change if it represents the cross-sectional area of the mouth area of the ciliate. However, conceivably, cilia could be oriented in a different manner under turbulent conditions. We should stress the possibility that the reductions in ingestion that we found could also represent a combination of changes in position of cilia, swimming speed as well as pattern. The impermanence of turbulence effects appears clear from the results of the 'on-off' experiment in which ciliate declines under turbulence were reversed when turbulence was stopped (Fig. 7).

Large changes in behavior associated with turbulence are known with regard to copepods. For example, Acartia tonsa displays increases in the frequencies and velocities of jumps (Saiz \& Alcaraz 1992). Interestingly, studies which have shown that turbulence can increase copepod ingestion rates have employed ciliates, specifically Strombidium sulcatum, as prey for copepods (Saiz \& Kiørboe 1995, Kiørboe et al. 1996, Caparroy et al. 1998). It has been recognized that 
turbulence may alter the behavior of both predator and prey (Caparroy et al. 1998) and our data suggests $S$. sulcatum behavior was quite likely different under still water or turbulent conditions, changing its susceptibility to predation.

The effects of turbulence on predators or particle consumers are now known to be much more complex than suggested by calculations of 'contact rates' (e.g. MacKenzie \& Kiørboe 2000). Here we add to the catalog of complex (i.e. species-specific) effects, with a possibly simple negative relationship between growth and turbulence, mediated by changes in ingestion in a marine oligotrich ciliate.

Acknowledgements. We thank F. Peters and FERM for designing and building the turbulence generator. This paper profited from the comments of the anonymous reviewers as well as Per Juel Hansen, Harry Havskum, Celia Marrasé, Francesc Peters, Robert Sanders and T. Frede Thingstad on earlier versions. Financial support for the work described was provided by the CNRS, Université de Paris VI, and the EU project NTAP (EVK3-CT-2000-00022). This paper is ELOISE contribution 351/40.

\section{LITERATURE CITED}

Allali K, Dolan J, Rassoulzadegan F (1994) Culture characteristics and orthophosphate excretion of a marine oligotrich ciliate, Strombidium sulcatum, fed heat-killed bacteria. Mar Ecol Prog Ser 105:159-165

Berdalet E (1992) Effects of turbulence on the marine dinoflagellate Gymnodinium nelsonii. J Phycol 28:267-272

Berdalet E, Estrada M (1992) The effects of turbulence on several dinoflagellate species. In: Smayda TJ, Shimizu Y (eds) Toxic phytoplankton blooms in the sea. Developments in marine biology, Vol. 3. Elsevier, Amsterdam, p 737-740

Bernard C, Rassoulzadegan F (1990) Bacteria or microflagellates as a major food source for marine ciliates: possible implications for the microzooplankton. Mar Ecol Prog Ser 64:147-155

Børsheim KY (1984) Clearance rates of bacteria-sized particles by freshwater ciliates, measured with monodisperse fluorescent latex beads. Oecologia 63:286-288

Caparroy P, Pérez MT, Carlotti F (1998) Feeding behaviour of Centropages typicus in calm and turbulent conditions. Mar Ecol Prog Ser 168:109-118

Christaki U, Dolan JR, Pelegri S, Rassoulzadegan F (1998) Consumption of picoplankton-size particles by marine ciliates: effects of physiological state of the ciliate and particle quality. Limnol Oceanogr 43:458-464

Christaki U, Jaquet S, Dolan JR, Vaulot D, Rassoulzadegan F (1999) Growth and grazing on Prochlorococcus and Synechococcus by two marine ciliates. Limnol Oceanogr 44: $52-61$

Costello JH, Strickler JR, Marrasé C, Trager G, Zeller R, Freise AJ (1990) Grazing in a turbulent environment: behavioural response of a calanoid copepod Centropages Hamatus. Proc Natl Acad Sci USA 87:1648-1652

Dolan JR, Simek K (1997) Processing of ingested matter in Strombidium sulcatum, a marine ciliate (Oligotrichida). Limnol Oceanogr 42:393-397

Fenchel T, Jonsson PR (1988) The functional biology of Strombidium sulcatum, a marine oligotrich ciliate (Ciliophora,
Oligotrichina). Mar Ecol Prog Ser 48:1-15

Gerritsen J, Strickler JR (1977) Encounter probabilities and community structure in zooplankton: a mathematical model. J Fish Res Board Can 34:73-82

Kiørboe T (1993) Turbulence, phytoplankton cell size, and the structure of plelagic food webs. Adv Mar Biol 29:1-72

Kiørboe T, MacKenzie B (1995) Turbulence-enhanced prey encounter rates in larval fish: effects of spatial scale, larval behaviour and size. J Plankton Res 17:2319-2331

Kiørboe T, Saiz E (1995) Planktivorous feeding in calm and turbulent environments, with emphasis on copepods. Mar Ecol Prog Ser 122:135-145

Kiørboe T, Saiz E, Viitasalo M (1996) Prey switching behaviour in the planktonic copepod Acartia tonsa. Mar Ecol Prog Ser 143:65-75

Lewis DM, TJ Pedley (2000) Planktonic contac rates in homogenous isotropic turbulence: theoretical predictions and kinematic simulations. J Theor Biol 205:377-408

MacKenzie BR, Kørboe T (1995) Encounter rates and swimming behavior of paus-travel and cruise larval fish predators in calm and turbulent laboratory environments. Limnol Oceanogr 40:1278-1289

MacKenzie BR, Kiørboe T (2000) Larval fish feeding and turbulence: a case for the downside. Limnol Oceanogr 45: $1-10$

Margalef R (1978) Life-forms of phytoplankton as survival alternatives in an unstable environment. Oceanol Acta 1: 493-509

Marrasé C, Costello JH, Granata T, Strickler JR (1990) Grazing rates in a turbulent environment: energy dissipîation, encounter rates and efficacy of feeding currents in Centropages hamatus. Proc Natl Acad Sci USA 87:1653-1657

Montagnes DJS, Taylor FRJ, Lynn DH (1990) Strombidium inclinatum n. sp. and a reassessment of Strombidium sulcatum Claparède and Lachmann (Ciliophora). J Protozool 37:318-323

Ohman MD, Snyder RA (1991) Growth kinetics of the omnivorous oligotrich ciliate Strombidium sp. Limnol Oceanogr 36:922-935

Oviatt CA (1981) Effects of different mixing schedules on phytoplankton, zooplankton and nutrients in marine microcosms. Mar Ecol Prog Ser 4:57-67

Pauly D (1989) An eponym for Reuben Lasker. Fish Bull 87: 383-384

Peters F, Gross T (1994) Increased grazing rates of microplankton in Response to small-scale turbulence. Mar Ecol Prog Se. 115:299-307

Peters F, Choi JW, Gross T (1996) Paraphysomonas imperforta (Protista, Chrysomonadida) under different turbulence levels: feeding, physiology and energetics. Mar Ecol Prog Ser 134:235-245

Peters F, Marrasé C, Havskum H, Rassoulzadegan F, Dolan J, Alcaraz M, Gasol JM (2002) Turbulence and the microbial food web: effects on bacterial losses to predation and on community structure. J Plankton Res 24:321-331

Petersen JE, Sanford LP, Kemp WM (1998) Coastal plankton responses to turbulent mixing in experimental ecosystems. Mar Ecol Prog Ser 171:23-41

Pollinger U, Zemel E (1981) In situ and experimental evidence of the influence of turbulence on cell division processes of Peridinium cinctum forma westii (Lemm.) Lefèvre. Br Phycol J 16:281-287

Rivier A, Brownlee DC, Sheldon RW, Rassoulzadegan F (1985) Growth of microzooplankton: a comparative study of bactivorous zooflagellates and ciliates. Mar Microb Food Webs 1:51-60

Rothschild BJ, Osborn TR (1988) Small-scale turbulence and 
plankton contact rates. J Plankton Res 10:465-474

Saiz E (1994) Observations on the free-swimming behaviour of the copepod Acartia tonsa: effects of food concentration and turbulent water. Limnol Oceanogr 39:1566-1578

Saiz E, Alcaraz M (1992) Free-swimming behaviour of Acartia clausi (Copepoda: Calanoida) under turbulent water movement. Mar Ecol Prog Ser 80:229-236

Saiz E, Kiørboe T (1995) Predatory and suspension feeding of the copepod Acartia tonsa in turbulent environments. Mar Ecol Prog Ser 122:147-158

Saiz E, Alcaraz M, Paffenhöfer GA (1992) Effects of smallscale turbulence on feeding rate and gross-growth efficiency of three Acartia species (Copepoda: Calanoida). J Plankton Res 14:1085-1097

Sherr EB, Sherr BF (1993) Preservation and storage of samples for enumeration of heterotrophic protists. In: Kemp PF, Sherr BF, Sherr EB, Cole JJ (eds) Handbook of methods in aquatic microbial ecology. Lewis Publishers, Boca Raton, FL, p 207-212

Shimeta J, Jumars PA (1991) Physical mechanisms and rates of particle capture by suspension feeders. Oceaongr Mar Biol Annu Rev 29:191-257

Shimeta J, Jumars PA, Lessard EJ (1995) Influences of turbulence on suspesion feeding by planktonic protozoa; exper-

Editorial responsibility: Robert Sanders,

Philadelphia, Pennsylvania, USA iments in laminar shear fields. Limnol. Oceanogr. 40: 845-859

Smayda TJ, Bienfang PK (1983) Suspension properties of various phyletic groups of phytoplankton and tintinnids in an oligotrophic subtropical system. PSZN: I Mar Ecol 4: 289-300

Thomas WH, Gibson CH (1990) Quantified small-scale turbulence inhibits a red tide dinoflagellate, Gonyaulax polyedra Stein. Deep-Sea Res 37:1583-1593

Thomas WH, Gibson CH (1992) Effects of quantified smallscale turbulence on the dinoflagellate, Gymnodinium sanguineum (splendens): contrasts with Gonyaulax (Linguldinium) polyedra, and the fishery implication. Deep-Sea Res 39:1429-1437

Thomas WT, Vernet M, Gibson CH (1995) Effects of smallscale turbulence on photosynthesis, pigmentation, cell division, and cell size in the marine dinoflagellate Gonyaulax polyedra (Dinophyceae). J Phycol 31:50-59

White AW (1976) Growth inhibition caused by turbulence in the toxic marine dinoflagellate Gonyaulax excavata. J Fish Res Board Can 33:2598-2602

Zirbel MJ, Veron F, Latz MI (2000) The reversible effect of flow on the morphology of Certatocorys horrida (Peridinales, Dinophyta). J Phycol 36:46-58

Submitted: August 15, 2002; Accepted: December 10, 2002 Proofs received from author(s): February 7, 2003 